RESEARCH NOTES

\title{
Pedagogical Conditions for The Formation of Professional Culture of Future Educators of Preschool Educational Institutions
}

\section{Condiciones pedagógicas para la formación de la cultura profesional de futuros educadores de instituciones educativas preescolares}

\author{
Alla Bogush* \\ South-Ukrainian K.D. Ushinskyi National Pedagogical University, Odesa, Ukraine. \\ ORCID: https://orcid.org/0000-0002-5678-5455 \\ Olena Kovshar \\ Kryvyi Rih State Pedagogical University, Kryvyi Rih, Ukraine. \\ ORCID: https://orcid.org/0000-0003-3407-8570

\section{Olena Kovtun} \\ National Aviation University, Kyiv, Ukraine. \\ ORCID: https://orcid.org/0000-0001-5216-6350

\section{Olena Bulgakova} \\ South-Ukrainian K.D. Ushinskyi National Pedagogical University, Odesa, Ukraine. \\ ORCID: https://orcid.org/0000-0002-1750-0349
}

*Correspondence

Email: alla.bogush@list.ru
Cite as:

Bogush, A., Kovshar, O., Kovtun, O., Bulgakova, O. (2020) Pedagogical Conditions for The Formation of Professional Culture of Future Educators of Preschool Educational Institutions. Propósitos y Representaciones, 8 (SPE2), e676. Doi: http://dx.doi.org/10.20511/pyr2020.v8nSPE2.676

(C) Universidad San Ignacio de Loyola, Vicerrectorado de Investigación, 2020. 


\section{Summary}

The article reveals the essence of the phenomenon "professional culture of future educators of preschool educational institutions" viewed as a complex integral formation within a holistic structure of a personality. It is characterized by a positive attitude to the subjects and objects of pedagogical activity (axiological component), deep and systematized professional knowledge, skills and competencies (cognitive component), as well as personal and professional qualities that reflect the level of mastery of a special area of knowledge (personal component) and find their manifestation in pedagogical activity (reflexive component). Criteria (specified by indicators) that characterize levels of professional culture development of future preschool educators have been determined, including: informational, motivational, behavioral and appraisal-creative. Pedagogical conditions for the formation of professional culture of future preschool educators in the process of their professional training have been substantiated. The above-mentioned pedagogical conditions presuppose: activation of educational activities of future preschool educators in the cultural and educational environment of a higher pedagogical institution; provision of interactive technological support for the educational process of future preschool educators; integration of the content of normative professional disciplines. The technique of forming the professional culture of future educators of preschool educational institutions is presented.

Keywords: Future Preschool Educators; Professional Culture; Professional Culture of Future Preschool Educators; Professional Training of Future Preschool Educators; Pedagogical Conditions; Method of Formation of Professional Culture of Future Preschool Educators.

\section{Resumen}

El artículo revela la esencia del fenómeno "cultura profesional de futuros educadores de instituciones educativas preescolares", visto como una formación integral compleja dentro de una estructura holística de una personalidad. Se caracteriza por una actitud positiva hacia los sujetos y objetos de la actividad pedagógica (componente axiológico), conocimiento profesional profundo y sistematizado, habilidades y competencias (componente cognitivo), así como cualidades personales y profesionales que reflejan el nivel de dominio de un especial área de conocimiento (componente personal) y encontrar su manifestación en la actividad pedagógica (componente reflexivo). Se han determinado los criterios (especificados por los indicadores) que caracterizan los niveles de desarrollo de la cultura profesional de los futuros educadores preescolares, que incluyen: informativo, motivacional, conductual y creativo de evaluación. Se han confirmado las condiciones pedagógicas para la formación de la cultura profesional de los futuros educadores preescolares en el proceso de su formación profesional. Las condiciones pedagógicas mencionadas anteriormente presuponen: la activación de las actividades educativas de los futuros educadores preescolares en el entorno cultural y educativo de una institución pedagógica superior; provisión de soporte tecnológico interactivo para el proceso educativo de futuros educadores preescolares; integración del contenido de disciplinas profesionales normativas. Se presenta la técnica de formar la cultura profesional de futuros educadores de instituciones educativas preescolares.

Palabras clave: Futuros educadores preescolares; Cultura professional; Cultura profesional de futuros educadores preescolares; Capacitación profesional de futuros educadores preescolares; Condiciones pedagógicas; Método de formación de cultura profesional de futuros educadores preescolares. 


\section{Introduction}

In the conditions of socio-economic changes in Ukraine, higher education has the task of training preschool education professionals who can be competitive in the labor market. Modern specialists have to master a certain optimal amount of diverse professional skills. Professional requirements are based on the level of knowledge of theoretical material, as well as on the ability to apply theoretical knowledge and practical skills in the performance of independent and creative tasks. Therefore, it is important in preparing future specialists for preschool educational institutions to give priority attention to the content of the curriculum and teaching methods applied so that they shape the outlook, critical thinking, ability to self-knowledge and self-realization of the individual in various activities, develop other competencies and skills necessary for life and professional choice. In this regard, the approach to determining the content of general and professional training in a higher pedagogical institution is changing.

The current practice of preparing future educators for preschool educational institutions shows that there is a contradiction between the need to improve the quality of training of future preschool educators and the lack of scientifically grounded concepts and technologies for the formation of professional culture as an integral element of professional education of preschool specialists.

The relevance of the research of the formation of professional culture of future preschool educators is conditioned by the requirements of the National Strategy for the Development of Education in Ukraine until 2021, the Higher Education Industry Standard, the Concept of Development of Education of Ukraine for the 2015-2025 period, as well as the Laws of Ukraine ("On Education", "On Higher Education") and other government regulations.

The publications of the research topic. Manifold issues of professional training and professional formation of future educators of preschool educational institutions were studied by such scientists as A. Bohush, O. Bulhakova, K. Konovalova, O. Kovshar, O. Kovtun, I. Lutsenko, N. Melnik (Bogush, 2019; Bulhakova, 2018; Kovshar, Palshkova, Savchenko, 2019; Kovtun, 2015; Lutsenko, 2013; Melnik et al., 2019) and others. Thus, the scientific-theoretical and practical importance of solving the problem led to the choice of the research topic: "Pedagogical conditions for the formation of professional culture of the future educators of preschool educational institutions".

The tasks of the research: 1) to reveal the essence and structure of the phenomenon "professional culture of future educators of preschool educational institutions"; 2) to clarify the concepts of "educator's professional culture", "professional training of future educators of preschool educational institutions"; 3) to define structural components, criteria, and their indicators; to reveal and substantiate pedagogical conditions necessary for the formation of professional culture of future educators of preschool educational institutions in the process of professional training; 4) to verify an experimental method of forming the professional culture of future educators of preschool educational institutions in the process of professional training.

\section{Research methods}

The methods of analysis and synthesis, comparison, classification and generalization of scientific approaches to the problem of research, presented in philosophical, sociological, psychological, pedagogical sources were used in order to determine the theoretical foundations of the phenomenon under study. The methods of empirical research and modeling were used to test the designed experimental methodology of forming professional culture of future preschool educators in the process of professional training; method of pedagogical experiment was applied in order to determine the effectiveness of pedagogical conditions that contribute to this process. The 
validation of the experimental data and their quantitative and qualitative analysis were performed using the methods of mathematical statistics.

The experimental-research work was carried out on the basis of Kryvyi Rih State Pedagogical University. The total number of participants at all stages of the experimental study was 56. 40 students participated in the forming stage of the experiment.

\section{The obtained results}

The analysis of dictionary sources convincingly proves that the concept of professional culture includes the working activity of a person and the quality results of such activity. The origins of professional culture come from the historical social division of labor, the emergence of various professions, the desire to distinguish the culture of work etc.

In the scientific studies (by such scientists as I. Isaiev, V. Kravtsov, N. Krylov, M. Mykhailychenko, V. Slastionin, V. Radul, Ye. Shyianov, etc.), general culture is viewed as the basis for professional culture including a certain level of education, features of the outlook, attitude to work, general upbringing, range of interests and requests, norms of everyday behavior.

The notion of "professional culture" is relatively new, as it became widespread in the Ukrainian pedagogy of the 1980s. Professional culture is "the most important spiritual quality of a person, manifested in the ability to find pleasure in the very process of work" (Lutsenko, 2013). The professional culture of a specialist is a systemic quality, the initial elements of which are knowledge, practical skills and own social qualities that characterize the person's attitude to the world of social values (Lutsenko, 2013).

H. Kochetov characterizes professional culture as an element of the model of personality of a specialist with higher education with such features as: knowledge of the properties of the product and consumer's requests, ability to predict the consequences of own actions taken by a specialist, and taking responsibility for own actions (Kochetov, 1975).

V. Grinova notes that professional culture is an objective qualitative indicator of the formation of both the subject of activity and its habitat; by the features of professional culture one can judge about society itself as a whole, and about many of its components: spheres, elements, parts (Grinova, 2000).

Describing professional culture, S. Yelkanov names such features as: harmonious mental, moral and aesthetic development, broad scientific and artistic-aesthetic outlook, ability to easily and naturally enter into a creative state, ability to analyze own emotional and volitional processes (Yelkanov, 1986).

We share the views of T. Ivanova who believes that the formation of future teachers' professional culture is the accumulation of knowledge, experience, and qualitative implementation of them in personal activities and behavior (Ivanova, 2005).

According to the results of analysis and generalization of the theoretical foundations of the formation of professional culture, it wass found out that the professional culture of a teacher is a characteristic of the level and quality of activity, which includes professional knowledge, practical skills, relevant competencies and personal qualities that relate to a particular type of work.

E. Bondarevska notes that the fundamental problem of professional training in the conditions of a higher educational institution is the process of social and professional maturation of a teacher, which is important to carry out in his (her) student years. We agree with this statement, because through obtaining pedagogical education a future educator must realize 
himself (herself) as a professional specialist, and a fully-formed professional, cultural and highly educated personality.

Therefore, the term "professional training of future educators of preschool educational institutions" is interpreted as an organized educational process aimed at mastering special knowledge, abilities and skills, development of personal and professional qualities necessary for further successful pedagogical activity.

The professional culture of future preschool educators is a complex integral formation within a holistic structure of a personality. It is characterized by a positive attitude to the subjects and objects of pedagogical activity (axiological component), deep and systematized professional knowledge, skills and competencies (cognitive component), personal and professional qualities that reflect the level of mastery of a special area of knowledge (personal component) and find their manifestation in pedagogical activity (reflexive component).

The pedagogical conditions for the formation of the professional culture of future educators of preschool educational institutions in the process of their professional training are defined as follows: activation of educational activities of future educators of preschool educational institutions in the cultural and educational environment of a higher pedagogical institution of education; provision of interactive technological support for the educational process of future preschool educators; integration of the content of normative professional disciplines.

The criteria with the relevant indicators were selected, including: informational criterion (awareness of the essence of professional culture; knowledge of specific nature of the professional culture of educators; knowledge of complex and partial programs as well as the Basic component of preschool education); motivational criterion (the presence of positive motivation for the professional activity of a preschool educator; awareness of the value of the profession of a preschool educator; the need for professional self-realization as well as cultural and pedagogical growth); behavioral criterion (awareness of the need for self-development of personal and professional qualities, which prove the formation of the professional culture of the educator (including empathy, communication, tact; the ability to use the formulas of speech etiquette in the process of communication with children and their parents; the ability to use the latest information technologies in the process of training); evaluative-creative criterion (the presence of reflexive skills in evaluation of the formation of professional culture; the presence of the ability to mutually evaluate the manifestations of professional culture in the behavior of colleagues; the ability to self-evaluate the manifestations of professional culture in the educator's own behavior).

According to the criteria and indicators, the levels of professional culture of future educators of preschool educational institutions in the process of professional training (high, sufficient, satisfactory, and low) have been determined.

Experimental and research work on the formation of professional culture included students (I, II, III years of study) of the educational level: "Bachelor"; in the specialty: 012 "Preschool education"; of Kryvyi Rih State Pedagogical University.

At the first motivational stage, the following pedagogical conditions were implemented: activation of the educational activity of future educators of preschool educational institutions in the cultural and educational environment of the higher pedagogical institution of education; provision of interactive technological support for the educational process of future preschool educators. All training activities were aimed at students' acquiring necessary knowledge regarding the essence of the concepts of "professional culture", as well as forming students' awareness of the importance of professional culture for teachers of preschool educational institutions. The main organizational forms of training were lectures with the use of the elements 
of conversation, lectures with interactive methods of teaching, lectures-discussions, laboratory classes, practicum seminar, business game seminars, practical classes with creative tasks, master classes, field trips to preschool educational establishments, individual work by the students, Skype video conferences, individual work of the teacher with students (providing scientific and methodological assistance in the performance of independent work tasks, Internet counseling, verification of the completion of the tasks of individual work, etc.), conducted within such educational disciplines as "Fundamentals of Pedagogical Skillfulness of Teachers", "Preschool Pedagogy".

Interviews ("Pedagogical values of the modern educator", "Pedagogical creativity as a component of professional training of the modern educator", "Professional culture as integral quality of the future educator"); disputes ("Professional self-improvement of the educator - is it necessary or not?", "Pedagogical skillfulness of the teacher of preschool educational institution as the highest level of his professional activity"); debate ("The idea of planning and implementation of an integrative approach in the pedagogical process with preschool children: advantages and disadvantages of applying an integrative approach from the pedagogue's and child's perspectives"); "Microphone" ("What functions should a modern educator perform?", "What makes a true master?", "What should a masterful educator be?", etc.); "Unfinished sentences" ("The characteristics of the professional culture of preschool educators are...", "The teacher's trademark is...", etc.); business games ("Steps required to reach pedagogical skillfulness", "Modern educator - what should it be?", "Culture of the language of the preschool educator"); technology "Didactics of Film" etc were used as interactive methods and techniques for forming professional culture of future educators.

In the course of studying disciplines belonging to the cycle of professional and practical training, in particular "Fundamentals of Pedagogical Skillfulness of Teachers" and "Preschool Pedagogy", the website http://doshkilnaosvita.000webhostapp.com/ was developed for future educators of preschool educational institutions. This site contains educational and methodical complexes of the abovementioned disciplines, plans and topics of classes; methodological recommendations for practical (seminar) and laboratory classes; tasks for independent work of students, problem situations and tasks, creative tasks that allowed to reveal the content of professional culture for pedagogical activity of the teacher; self-test questions, tests, dictionaries etc.

Internet counseling provided an opportunity to discuss problem questions with the students ("What kind of a teacher would you call a master in his trade?", "Modern educator as a carrier of professional culture", "What should be changed in the professional training of a future preschool educator in accordance with modern requirements?", "What should become the model of the modern educator?"), and to express their own position on the professional tasks of the educator, to dispute, and also to gain experience of collective activity.

At the second (activity-based creative) stage, the following pedagogical condition was introduced: integration of the content of normative professional disciplines, which envisaged the formation and testing of practical skills by means of lectures, seminars and practical classes according to the module: "Fundamentals of formation of professional culture of the future educators of preschool educational institutions" within the scope of the educational discipline: "Preschool Pedagogy". Students got acquainted with essence of the concepts "profession", "professionalism", "culture". They also analyzed such phenomena as "professional culture", "pedagogical culture", "professional-pedagogical culture". Requirements to the educator as a subject of professional culture, as well as the professional and personal qualities of educators of preschool educational institutions and also the main professional pedagogical values were discussed in the classroom. Much attention was paid to the features of speech etiquette in the professional culture of educators. 
Practical classes in the discipline: "Preschool Pedagogy" were held taking into account the specific pedagogical activity of the teacher. Pedagogical situations and exercises ("Brownian Motion", "Create a New Game") were chosen as active forms of formation of professional culture; creative tasks aimed at forming the ability to solve professional tasks from the standpoint of manifestation of professional culture; miniature essays ("Professional portrait of a modern educator", "Professional culture as a basis for the development of the teacher's personality"), reflective essays ("The value of professional culture in the pedagogical activity of the educator", "The image of preschool educator") were used as well.

At the resultant evaluation stage, the priority was given to such pedagogical conditions as provision of interactive technological support for the educational process of future educators of preschool educational institutions; integration of the content of normative professional disciplines. This allowed formation of students' reflexive and analytical skills, their ability to selfassess the level of formation of professional culture and the ability to professional selfimprovement.

The improvement of professional skills was enhanced through involving students into elective course titled: "Practical aspects of formation of professional culture of future educators of preschool educational institutions". Students performed active exercises, such as: "I do not want to brag, but I...", "Magic box", "Qualities and skills required for effective communication", "My positive qualities", "Feel your partner", "Gossip", "Non-verbal sketches", "Stereotype glasses", "Commissary shop", "Initials", "Owner, house, hurricane", "Portrait of a perfect educator", "Nobel Prize", "Compliments", "Commandments", "How to increase motivation to learn", "Labels", aimed at the formation of professional culture of the future preschool educators, the culture of pedagogical communication, communication behaviors in a variety of situations, and organizational skills of interpersonal interaction.

The formation of professional culture of future educators in the process of pedagogical practice was ensured by the fulfillment of educational and research tasks, such as: creating a model titled "The portrait of a modern educator"; analyzing verbal communication of the educator with the children, based on two lingual standpoints: the content of communication and the culture of the teacher's language in communication; studying and summarizing the experience of pedagogical activity of one of the educators of preschool educational institutions, etc.

The results of pedagogical practice were considered at the final conferences in the form of a round table. During the conferences, the students prepared such videos as: "Professional culture of the preschool educator", "Speech culture and speech etiquette in the teacher's professional activity", "Mastery of pedagogical interaction in the teacher's professional activity"; staging pedagogical situations was also used. Following the results of the pedagogical conferences, the recommendations on taking the professional culture of educators to a higher level were offered and discussed by the students.

\section{Conclusion}

At the end of the forming stage of the experiment, a final check was made in order to clarify the effectiveness of certain pedagogical conditions stated in the experimental method.

The statistical reliability of the results of the forming stage of the research was verified using Pearson criterion $\chi 2$. The empirical value of Pearson criterion $\chi 2=40.253$, which exceeds the calculated value of $\chi 20.05(7,815)$ and $\chi 20.01(11.345)$ at $v=3$. Thus, the data obtained at the final stage of the experiment proved to be statistically significant, which proves the effectiveness of the experimental method of forming the professional culture of future educators of preschool educational institutions in the process of their professional training. 
The professional culture of the teacher is a characteristic of the level and quality of his (her) activity, which involves professional knowledge, practical skills, essential abilities, and personal qualities relevant to a particular type of work. Professional training of future educators of preschool educational institutions is an organized educational process aimed at mastering special knowledge, competencies and skills, as well as the development of personal and professional qualities required for further successful pedagogical activity.

It is established that the professional culture of future educators of preschool educational institutions is a complex integral formation within a holistic structure of personality, characterized by a positive attitude to the subjects and objects of pedagogical activity, deep and systematized professional knowledge, competencies and skills, personal and professional qualities which reflect the level of professional mastering of the area of expertise (preschool education) and find their expression in pedagogical activity.

The pedagogical conditions for the formation of the professional culture of future educators of preschool educational institutions in the process of their professional preparation are: activation of the educational activity of future educators of preschool educational institutions in the cultural and educational environment of a higher pedagogical institution of education; provision of interactive technological support for the educational process of future preschool educators; and integration of the content of normative professional disciplines.

The conducted study does not cover all the aspects related to the formation of professional culture of future educators of preschool educational institutions in the process of their professional training. The prospect of further scientific research is spotted by us in the study of the individual features of the process of self-development of professional culture of future preschool educators, which influence the results and dynamics of its formation; as well as the technology of formation of professional culture in extra-curricular time, which helps to improve the quality of professional training of future preschool educators; and also the pedagogical conditions for the development of professional culture of graduates in the specialty: "Preschool Education" after completion of studies at a higher educational institution..

\section{References}

Bogush, A.M. (2019). Methodology- and speech-oriented training of the future Master students majoring in Preschool Education. Scientific bulletin of South Ukrainian National Pedagogical University named after K.D. Ushynsky, 3(128), 9-14.

Bulhakova, O. (2018). Students' psychological readiness for social interaction: system and subjective approach. Science and Education, 1, 117-123.

Grinova, V.M. (2000). Formation of pedagogical culture of future teacher (theoretical and methodical aspects). Kyiv: Znannia.

Ivanova, T.V. (2005). Culturological training of a future teacher: monograph. Kyiv: CVP.

Kochetov, G.M. (1975). Mechanisms of the professionalization process. Tomsk: TSU.

Kovshar, O.V., Palshkova, I., Savchenko, L. (2019). Interaction of Productive Technologies in the Educational Process of Higher School. Amazonia Investiga, 8(20), 229-235.

Kovtun, O.V. (2015). Communicative approach to development of future preschool teachers' speech expressiveness. Science and Education, 6/CXXXV, 155-160.

Lutsenko, I.O. (2013). Theoretical and methodical principles of training future educators for the organization of communication and speech activity of children of the senior preschool age: doctor's thesis. Kyiv: CPV.

Melnik, N., Bidyuk, N., Kalenskyi, A., Maksymchuk, B., Bakhmat, N., Matviienko, O., Matviichuk, T., Solovyov, V., Golub., N., Maksymchuk, I. (2019). Models and organisational characteristics of preschool teachers' professional training in some EU countries and Ukraine. Zbornik Instituta za pedagoska istrazivanja, 51(1), 46-93.

Yelkanov, S.B. (1986). Professional self-education of a teacher. Moscow: Education. 